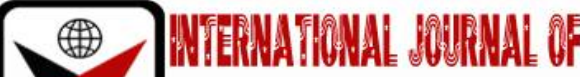

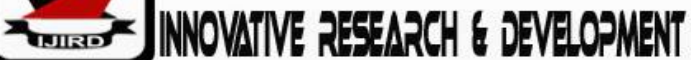

ISSN 2278-0211 (Online)

\section{Effect of Goniopsis Pelli (Marine Crab) Extract on Hematology and Lungs Histology in Swiss Mice Infected with Bordetella Pertussis}

Enyi, I. $\mathbf{~ . ~}$
Graduate Student, Department of Animal and Environmental Biology,
University of Port Harcourt, Nigeria
Hart, A. I.
Professors, Department of Animal and Environmental Biology,
University of Port Harcourt, Nigeria
Siminialayi, I. M.
Lecturer, Department of Pharmacology, University of Port Harcourt, Nigeria

\begin{abstract}
:
Pertussis is a global endemic infectious disease with outbreaks every 3-5 years is associated with lungs inflammations and hematological alterations. This study is aimed at investigating the changes in hematological parameters and histopathological changes of the lungs associated with Bordetella pertussis infection in swiss mice and to evaluate the ability of Goniopsis pelli extract to reverse these adverse changes in relation to erythromycin treatment. The animals were divided into five groups: group 1 was normal control, group 2 was infected with Bordetella pertussis without treatment (negative control), group 3 and 4 were Bordetella pertussis infected and treated with $300 \mathrm{mg} / \mathrm{kg}$ and $600 \mathrm{mg} / \mathrm{kg}$ of the extract respectively and group 5 was infected and treated with $4000 \mathrm{mg} / 70 \mathrm{~kg}$ of erythromycin in divided doses. The animals were inoculated with a single infective dose of Bordetella pertussis bacteria and were consequently treated with the graded doses of the extract and erythromycin for a period of eighteen days, after the animals were confirmed infected. The mice were humanely sacrificed using diethyl ether anesthesia and blood samples taken for hematological investigation and lungs tissue harvested and processed for histological examination. The result shows that Goniopsis pelli extract reversed the changes in the hematological parameters and pathological changes in the lungs of mice induced by Bordetella pertussis infection of in a dose and time dependent manner which suggests that prophylactic and curative potentials of Goniopsis pelli extract against B. pertussis.
\end{abstract}

Keywords: Bordetella pertussis, mice, Goniopsis pelli extract, hematology, lungs histology

\section{Introduction}

Pertussis is a global endemic infectious disease, with outbreaks every 3-5 years (CDC, 2012). World Health Organisation (WHO) reported that in 2008 approximately 16 million cases of pertussis occurred worldwide with 95\% occurring in developing countries and causing about 195000 deaths in children (WHO, 2010)B. pertussisremains a key universal pathogen that affects infants, children, and adults (Dorji et al., 2017), it is a complicated bacterium that expresses numerous bacterial factors with immune modulating functions and produces different bacterial factors responsible for the symptoms seen during the disease (Mattoo and Cherry, 2005). Pertussis is mostly a toxin mediated disease. The bacteria close to the cilia of the respiratory epithelial cells produce toxins that paralyze the cilia, and cause inflammation of the respiratory tract, which interferes with the clearing of pulmonary secretions (Sheridan et al., 2012). Pertussis antigens appear to allow the organism invade host defenses by enhancing lymphocytosis but impairing chemotaxis (NCDC, 2011).The understanding of this leaves us with the question of why has pertussis remained a major challenge to conquer internationally and what are the imminent dangers if nothing is done to curtail the prevalence of this disease. several studies have progressively proven that pertussis toxin (PT) is the leukocytosis enhancing factor that is produced by Bordetella pertussis. Furthermore, other experimental animals, including rats (Samore and Siber 1992), pigs (Elahi et al., 2005) and macaques (Hinds et al., 1996; Pauza et al., 1997), develop leukocytosis (an increase in the number of white blood cell especially during infection) when administered purified pertussis toxin (PT). Mice and baboons inoculated with $B$. pertussis have lowered levels of leukocytosis when induced with PT-specific monoclonal antibodies (Nguyen et al., 2015). In a study by Temple et al., (2009) to determine the influence of living Bordetella pertussis on the induction and duration of patho-physiological reactions in mice infected intranasally with graded doses of culture, reported that fatally infected mice showed loss of body weight, spleen atrophy, obvious hypothermia and hypoglycemia (low blood sugar), and highly increased levels of leukocytes and serum immune-reactive insulin while non fatal infected 
mice showed normal weight gain, almost normal temperature, spleen enlargement, not too pronounced hypoglycemia, lower but obvious increased levels of leukocytes and serum immune-reactive insulin, and histamine sensitization.Leukocytosis (an increase in the number of white blood cell especially during infection) and lymphocytosis (an increase in the number of lymphocytes in the blood) are clear indications of pertussis infection (Beck et al., 2014). Similarly, Momoh et al., (2013) noted that infection with $S$. typhi, similar bacteria to the one under study produced a reduction in pack cell volume (PCV), Red blood cell (RBC) and Hemoglobin (Hb) while there was an increase in monocyte, neutrophil and WBC but there was no significant difference. Crabs are decapod crustaceans which belong to the infra order Brachyura. They are mainly covered with thick exoskeleton. Their lower region is completely hidden under the thoracic cavity. They can be found in most tropical and subtropical regions of the world as reported by Sammy et al., (2009). The marine crab (Goniopsis pelli) which belong to the family Grapsidae, are macro benthos which are regular constituents of tropical and subtropical estuarine systems. They feed on fish, aquatic vegetation, molluscs, crustaceans and annelids. They are known to be good sources of essential macro and micro minerals such as potassium, phosphorus, calcium, magnesium, copper, iron, manganese, and zinc. Bae (2010) and Sujeetha et al., (2015) reported the biomedical and nutritional properties of crabs to include Omega3 (a poly unsaturated acid) contained in crab meat which helps in providing protection against heart diseases and inhibit the aggressive behavior. Mahae et al., (2011) noted that the selenium contained in crab meat plays an important role in human's antioxidant defense system by preventing cells and tissues from damage and helps in proper functioning of the immune system and metabolism of thyroid hormone while riboflavin present in them helps in the production of steroids and red blood cells, maintenance of the skin, promote normal growth and iron absorption from the digestive tract and support antioxidant activity. Garry (2015) explained that copper and phosphate content in crab helps in the absorption, storage and metabolism of iron and is involved in the formation of red blood cells. Ming et al., (2010) and Suneeta (2014) in their separate studies reported that crabs lower blood pressure, protect against heart diseases and possess anti inflammatory properties. Chitosan derived from crab shell have several properties including anti-microbial and antibacterial properties due to its peculiar characteristics (Mahae et al., 2011). Chitosan fights against numerous pathogenic organisms like fungi, spoilage microorganisms, gram positive and gram negative bacteria (Mahae et al., 2011). However, this is the first attempt at establishing the antibacterial effects of crab extract which was predisposed by subjective evidence of the restorative potential of crabs in whooping cough among the bonny people of Rivers State, Nigeria. This study is aimed at determining the effect of Goniopsis pelli extract on hematology and lungs histology in swiss mouse infected with Bordetella pertussis

\section{Material and Methods}

\subsection{Sample Collection and Identification}

Goniopsis pelli was collected at low tide in the mangrove shores by hand picking in the buguma creek, Rivers State, Nigeria. The samples collected were transferred into perforated plastic containers to allow for air during transportation and was transported to the Pharmacognosy research laboratory, Department of Pharmacognosy, University of Port Harcourt, Nigeria. The samples were identified Mr. Otufu Paciya using Food and Agriculture Organization species identification sheets for fresh water and marine crab species.

\subsection{Method of Extraction}

Using the Shahidi and Synowiecki (1991) extraction method, 60 of the freshly collected crabs were sacrificed and the shell separated from the meat and washed with tap water to remove all impurities. The crab shells and meat were then transferred to the oven and dried at $70^{\circ} \mathrm{C}$ until they were completely dry. Using a laboratory mortar and pistle, the dried crab shells and meat were ground and sieved into the size of $500 \mu \mathrm{m} .40 \mathrm{~g}$ of the sieved crab was measured using WANT precision electric weighing balance made by want balance instrument company limited, China into a beaker and $200 \mathrm{ml}$ of cod liver oil was added and stirred with magnetic stirrer until it was completely mixed for 20 minutes. The beaker was then transferred into a water bath at a temperature of $60^{\circ} \mathrm{C}$ and allowed for $30 \mathrm{mins}$. The mixture was then filtered with a white handkerchief to drain off the oil and the residue transferred into a beaker. The residue was treated with $2 \%$ potassium hydroxide $(\mathrm{KOH})$ at a ratio of $1: 20 \mathrm{w} / \mathrm{v}$ and was stirred continuously for 2 hours at a temperature of $90^{\circ} \mathrm{C}$ to remove protein from the crab. The sample was filtered under vacuum and the residues were continuously washed until the $\mathrm{pH}$ became neutral i.e. $\mathrm{pH}=7$. This was done to ensure that all the salt had been removed after removing the protein. The deproteinized crab was transferred into an oven and dried at $60^{\circ} \mathrm{C}$ until it was completely dry (Shahidi and Synowiecki, 1991). $2.5 \% \mathrm{w} / \mathrm{v}$ of hydrochloric acid $(\mathrm{Hcl})$ was used at room temperature $\left(20^{\circ} \mathrm{C}\right)$ for 6 hours to remove the mineral content of the deproteinized crab at a ratio of 1:20 w/v. The samples were filtered under vacuum and washed with tap water until the $\mathrm{pH}$ was neutral. The demineralized crab were then transferred to the oven and dried at a temperature $60^{\circ} \mathrm{C}$ until completely dried. (Shahidi and Synowiecki, 1991).The demineralized crab was treated with 300ml acetone for $10 \mathrm{mins}$ and dried for $2 \mathrm{hrs}$ at an ambient temperature and the residues were removed to achieve decolourization. The decolourized sample was washed in running water, filtered and dried at $60^{\circ} \mathrm{C}$ until it was completely dried to obtain crab chitin (Shahidi and Synowiecki, 1991).Deacetylation of chitin was carried out using the method of Yen et al., (2009). The obtained chitin was treated with $40 \% \mathrm{w} / \mathrm{v}$ aqueous sodium hydroxide (NaoH) in the ratio of chitin to the solution $1: 15 \mathrm{w} / \mathrm{v}$ at $105^{\circ} \mathrm{C}$ in a water bath for $2 \mathrm{hrs}$. Thereafter, the chitin was filtered with filter pump and washed with deionized water until $\mathrm{pH}$ was neutral to obtain the extract. The obtained extract was then dried at $60^{\circ} \mathrm{C}$ for $2 \mathrm{hrs}$ in the oven. The dried extract was preserved in a well labeled bottle and kept for the experiment. 


\subsection{Isolation of Test Organism}

The test organism Bordetella pertussis (ATCC ${ }^{\circledR 9} 9340^{\mathrm{TM}}$ ) was gotten from the American Type Culture Collection (ATCC), USA. The culture media used for isolation according to ATCC is medium 35: Bordet Gengou/Broth medium from a human clinical specimen at a growth temperature of $37^{\circ} \mathrm{C}$ in aerobic atmosphere. The product was received freeze-dried at $2^{\circ} \mathrm{C}-8^{\circ}$ Cand stored at $-80^{\circ} \mathrm{C}$. The bacterium was reconstituted using Regan-Lowe agar (Charcoal blood Agar) in the Department of Microbiology laboratory, University of Port Harcourt.

\subsection{Experimental Design}

A total of one hundred and twenty-two (122) animals (swiss mice) were divided into five groups for the curative treatment study. Group 1 (normal) had 10 animals, group 2 (negative control) had 28 animals; group 3 and 4 consisted of 28 swiss mice each. Group 1 served as the normal control without treatment but was fed with the normal animal feed and water. Group 2 (negative control group) consisted of B. pertussis inoculated mice without treatment. Group 3 consisted of B.pertussis infected mice exposed to low dose $(300 \mathrm{mg} / \mathrm{kg})$ of Goniopsis pelli extract while group 4 consisted of B. pertussis infected mice exposed to high dose $(600 \mathrm{mg} / \mathrm{kg})$ of Goniopsis pelli extract and group 5 consisted of B. pertussis infected mice exposed to $4000 \mathrm{mg} / 70 \mathrm{~kg}$ of erythromycin. On day 0 , at day 6days interval and on day 18, seven animals were sacrificed using diethyl ether anesthesia; samples of blood were collected and the liver removed for assessment of liver function status and histho-pathological examination respectively.

\subsection{Challenging apparently healthy animals with Bordetella pertussis infective dose}

One hundred and twenty-two animals were intraperitonially challenged with the infective dose of Bordetella pertussis which was calculated to be $5 \times 10^{5} \mathrm{cfu} / \mathrm{ml}$. After infection had set in (through physical observation of signs like weakness, non-productive cough, anorexia and the isolation of the organism from the blood of the infected animals on day 0 ) seven animals were sacrificed and blood samples and liver tissue was collected for preliminary investigation and the rest animals from the other treatment groups were given two times daily of the various doses of the extract and the standard antibiotics (erythromycin) for 18days.

\subsection{Antibiotic and Extract Concentration Preparation}

The extract solution for the study was prepared by dissolving $0.5 \mathrm{~g}$ of the extract in $1 \mathrm{ml}$ of di-methyl-sulfoxide (DMSO) solvent to have a stock concentration of $500 \mathrm{mg} / \mathrm{ml}$. Since $70 \mathrm{~kg}(70000 \mathrm{~g})$ takes $4000 \mathrm{mg}$ of erythromycin daily at severe case of whooping cough, then $25 \mathrm{~g}$ (average weight of test animal) will take $25 \mathrm{~g} \times 4000 \mathrm{mg} / 70000 \mathrm{~g}=1.429 \mathrm{mg}$. This means that $25 \mathrm{~g}$ will take $1.429 \mathrm{mg} / \mathrm{ml}$ or $2.858 \mathrm{mg} / 0.5 \mathrm{ml}(1.429 \times 2)$ or $5.716 \mathrm{mg} / 0.25 \mathrm{ml}(1.429 \times 4) .5 .716 \mathrm{mg} / 0.25 \mathrm{ml}$ was prepared from $500 \mathrm{mg}$ tablet of erythromycin tablet thus $500 \mathrm{mg} / \mathrm{Xml}=5.716 \mathrm{mg} / \mathrm{ml}$. therefore, $\mathrm{X}=500 \mathrm{mg} \mathrm{x} \mathrm{ml} / 5.716 \mathrm{mg}=$ $87.47 \mathrm{ml}$. Hence, $500 \mathrm{mg}$ tablet of erythromycin was dissolved in $87.47 \mathrm{ml}$ distilled water to prepare the erythromycin solution for the study.

\subsection{Blood Collection}

Each animal was anaesthetized with diethyl ether in a desiccator and blood was collected by cardiac puncture method and transferred into a well labeled sample bottles containing anti-coagulant.

\subsubsection{Hematological Analysis}

The hematological analysis was carried out using the method as described by Randox Laboratories Limited, United Kingdom.

\subsubsection{Histopathology Studies}

The study animals (swiss mice) were subjected to diethyl ether anesthesia in a desiccator and dissected aseptically to collect the liver for histopathological studies. The collected tissues were kept in $10 \%$ chloroform for preservation and were subsequently trimmed to the size of $3-4 \mathrm{~mm}$ thickness for fixation. These tissues were fixed, dehydrated, cleared, impregnated, embedded, sectioned and stained with hematoxylin and eosin before mounting according to the method described by Baker (1945).

\subsubsection{Statistical Analysis}

The results of the measurements are shown as Mean \pm Standard Deviation of Mean. The mean differences were obtained by ANOVA and post hoc with least significant difference (LSD) (Mead \& Curnow, 1982).

\section{Results}

\subsection{Effect of Goniopsis pelli extract on Post-Inoculation Treatment on Hematological Indices in B. Pertussis Infected Mouse}

From the result, inoculation of mice with infective dose of $B$. pertussis reveals a gradual decrease in PCV, Hemoglobin, Figure let, RBC and Eosinophil levels when compared to the normal control but these alterations was reversed when treated with Goniopsis pelli extract. Treatment with Goniopsis pelli extractreveals a steady increase in PCV (table 1) Hemoglobin (table 2) figure let (table 3) RBC (table 4) as the day progresses. Contrarily, the negative control shows a constant decrease in all the parameters as the day progresses. Statistical ANOVA comparison shows a significant difference $(\mathrm{p}<0.05)$ between normal control, negative control, standard drug and the treated groups on $6^{\text {th }}, 12^{\text {th }}$ and $18^{\text {th }}$ day. Similarly, inoculation with an infective dose of B. pertussis shows an increase in WBC, neutrophils, lymphocytes and 
monocytes when compared with the normal control. However, treatment with Goniopsis pelli extractreversed the variations causing a gradual decrease in the hematological parameters (neutrophils, lymphocytes, WBC and monocytes). ANOVA comparison between the normal control, negative control, standard drug and the treatment group shows a significant difference in WBC on day 6,12 and 18. Also, neutrophils showed no significant ( $p>0.05$ ) difference on day 12 when compared to standard drug and day 18 when compared to control and standard drug. Similarly, there was a significant difference $(\mathrm{P}<0.05)$ in lymphocytes on day 6 and12 but showed no significant $(\mathrm{P}>0.05)$ on day 18 when compared to the normal control and standard drug. Finally monocytes count showed no significant difference in relation to standard drug on day 6 and 12 but a significant difference $(\mathrm{P}<0.05)$ when compared to negative control on day 18

\begin{tabular}{|c|c|c|c|c|}
\hline & DAY 0 & DAY 6 & DAY 12 & DAY 18 \\
\hline Control & $37.00 \pm 0.000$ & $37.00 \pm 0.000$ & $37.00 \pm 0.000$ & $37.00 \pm 0.000$ \\
\hline Negative control & $24.67 \pm 1.155$ & $22.33 \pm .577$ & $18.67 \pm 1.155$ & $15.33 \pm 1.155$ \\
\hline Erythromycin & $24.67 \pm 1.155$ & $28.33 \pm .577$ & $34.33 \pm .577$ & $36.67 \pm .577$ \\
\hline Low dose & $24.67 \pm 1.155$ & $26.33 \pm .577$ abc & $27.67 \pm .577$ abc & $28.67 \pm 1.155^{\mathrm{abc}}$ \\
\hline High dose & $24.67 \pm 1.155$ & $26.33 \pm .577 \mathrm{abc}$ & $29.67 \pm .577 \mathrm{abc}$ & $32.33 \pm .577 \mathrm{abc}$ \\
\hline
\end{tabular}

Table 1: Effect of Post - Inoculation Treatment with Goniopsis Pelli Extract on PCV (g/dl)] in B. Pertussis Infected Mice

$\mathrm{a}=$ Significant $(\mathrm{p}<0.05)$ between test groups and control

$\mathrm{b}=$ Significant $(\mathrm{p}<0.05)$ between test groups and negative control

$\mathrm{c}=$ Significant $(\mathrm{p}<0.05)$ between test groups and erythromycin

Control = Animal fed with normal feed and water

Negative control $=$ Animal infected with Bordetella pertussis without treatment

Low dose $=300 \mathrm{mg} / \mathrm{kg}$

High dose $=600 \mathrm{mg} / \mathrm{kg}$

Erythromycin $=$ standard antibiotics drug

\begin{tabular}{|c|c|c|c|c|}
\hline & DAY 0 & DAY 6 & DAY 12 & DAY 18 \\
\hline Control & $12.30 \pm 0.000$ & $12.30 \pm 0.000$ & $12.30 \pm 0.000$ & $12.30 \pm 0.000$ \\
\hline Negative control & $8.40 \pm .200$ & $7.47 \pm .115$ & $7.00 \pm .173$ & $6.47 \pm .153$ \\
\hline Erythromycin & $8.40 \pm .200$ & $9.13 \pm .208$ & $11.10 \pm .173$ & $12.20 \pm .100$ \\
\hline Low dose & $8.40 \pm .200$ & $8.33 \pm .058 \mathrm{abc}$ & $8.70 \pm .200 \mathrm{abc}$ & $9.10 \pm .173 \mathrm{abc}$ \\
\hline High dose & $8.40 \pm .200$ & $8.37 \pm .115 \mathrm{abc}$ & $9.53 \pm .252 \mathrm{abc}$ & $10.00 \pm .173 \mathrm{abc}$ \\
\hline
\end{tabular}

Table 2: Effect of Post - Inoculation Treatment with Goniopsis Pelli Extract on

$\mathrm{Hgb}(\mathrm{g} / \mathrm{dl})]$ in B. Pertussis Infected Mice

\begin{tabular}{|c|c|c|c|c|}
\hline & DAY 0 & DAY 6 & DAY 12 & DAY 18 \\
\hline Control & $100.00 \pm 0.000$ & $100.00 \pm 0.000$ & $100.00 \pm 0.000$ & $100.00 \pm 0.000$ \\
\hline Negative control & $56.00 \pm 0.000$ & $53.33 \pm 1.155$ & $50.33 \pm .577$ & $48.33 \pm .577$ \\
\hline Erythromycin & $56.00 \pm 0.000$ & $73.67 \pm 3.512$ & $85.00 \pm 2.000$ & $99.33 \pm .577$ \\
\hline Low dose & $56.00 \pm 0.000$ & $59.33 \pm 1.155^{\mathrm{abc}}$ & $62.00 \pm 1.732^{\mathrm{abc}}$ & $66.33 \pm 1.155^{\mathrm{abc}}$ \\
\hline High dose & $56.00 \pm 0.000$ & $63.67 \pm .577^{\mathrm{abc}}$ & $69.33 \pm 3.055^{\mathrm{abc}}$ & $76.33 \pm 1.155^{\mathrm{abc}}$ \\
\hline
\end{tabular}

Table 3: Effect of Post - Inoculation Treatment with Goniopsis Pelli Extract on

Figure Lets Count $\left.\left(X 10^{3} / \mu \mathrm{l}\right)\right]$ In B. Pertussis Infected Mice

\begin{tabular}{|c|c|c|c|c|}
\hline & DAY 0 & DAY 6 & DAY 12 & DAY 18 \\
\hline Control & $9.29 \pm 0.000$ & $9.29 \pm 0.000$ & $9.29 \pm 0.000$ & $9.29 \pm 0.000$ \\
\hline Negative control & $4.90 \pm .300$ & $4.50 \pm .200$ & $3.77 \pm .115$ & $3.07 \pm .153$ \\
\hline Erythromycin & $4.90 \pm .300$ & $6.33 \pm .058$ & $7.90 \pm .200$ & $9.28 \pm .017$ \\
\hline Low dose & $4.90 \pm .300$ & $5.17 \pm .115^{\mathrm{abc}}$ & $5.47 \pm .115^{\mathrm{abc}}$ & $5.87 \pm .058^{\mathrm{abc}}$ \\
\hline High dose & $4.90 \pm .300$ & $5.70 \pm .173^{\mathrm{abc}}$ & $6.20 \pm .200^{\mathrm{abc}}$ & $7.10 \pm .173^{\mathrm{abc}}$ \\
\hline
\end{tabular}

Table 4: Effect of Post - Inoculation Treatment with Goniopsis

Pelli Extract on $R B C\left(\times 10^{3} / \mu l\right)$ in B. pertussis infected mice

\begin{tabular}{|c|c|c|c|c|}
\hline & DAY 0 & DAY 6 & DAY 12 & DAY 18 \\
\hline Control & $5.10 \pm 0.000$ & $5.10 \pm 0.000$ & $5.10 \pm 0.000$ & $5.10 \pm 0.000$ \\
\hline Negative control & $5.77 \pm .058$ & $6.43 \pm .153$ & $7.70 \pm .173$ & $9.27 \pm .153$ \\
\hline Erythromycin & $5.77 \pm .058$ & $5.33 \pm .058$ & $5.20 \pm 0.000$ & $5.13 \pm .058$ \\
\hline Low dose & $5.77 \pm .058$ & $5.77 \pm .058^{\mathrm{abc}}$ & $5.73 \pm .058^{\mathrm{abc}}$ & $5.67 \pm .058^{\mathrm{abc}}$ \\
\hline High dose & $5.77 \pm .058$ & $5.77 \pm .058^{\mathrm{abc}}$ & $5.57 \pm .058^{\mathrm{abc}}$ & $5.43 \pm .058^{\mathrm{abc}}$ \\
\hline
\end{tabular}

Table 5: Effect of Post - Inoculation Treatment with Goniopsis Pelli Extract on $W B C\left(X 10^{3} / \mu l\right)$ in B. Pertussis Infected Mice 


\begin{tabular}{|c|c|c|c|c|}
\hline & DAY 0 & DAY 6 & DAY 12 & DAY 18 \\
\hline Control & $20.00 \pm 0.000$ & $20.00 \pm 0.000$ & $20.00 \pm 0.000$ & $20.00 \pm 0.000$ \\
\hline Negative control & $24.67 \pm 1.155$ & $27.33 \pm .577$ & $30.00 \pm 1.000$ & $42.00 \pm 1.732$ \\
\hline Erythromycin & $24.67 \pm 1.155$ & $21.67 \pm .577$ & $21.00 \pm 0.000$ & $20.00 \pm 0.000$ \\
\hline Low dose & $24.67 \pm 1.155$ & $24.00 \pm 0.000^{\mathrm{abc}}$ & $23.67 \pm .577 \mathrm{abc}$ & $23.33 \pm .577 \mathrm{abc}$ \\
\hline High dose & $24.67 \pm 1.155$ & $23.67 \pm .577 \mathrm{abc}$ & $22.67 \pm .577 \mathrm{abc}$ & $22.33 \pm .577 \mathrm{abc}$ \\
\hline
\end{tabular}

Table 6: Effect of Post - Inoculation Treatment with Goniopsis Pelli Extract on Neutrophil Count $\left(X 10^{3} / \mu l\right)$ In B. Pertussis Infected Mice

\begin{tabular}{|c|c|c|c|c|}
\hline & DAY 0 & DAY 6 & DAY 12 & DAY 18 \\
\hline Control & $82.00 \pm 0.000$ & $82.00 \pm 0.000$ & $82.00 \pm 0.000$ & $82.00 \pm 0.000$ \\
\hline Negative control & $88.00 \pm 1.000$ & $91.33 \pm 2.082$ & $94.00 \pm 1.000$ & $101.67 \pm 2.517$ \\
\hline Erythromycin & $88.00 \pm 1.000$ & $84.33 \pm .577$ & $83.67 \pm .577$ & $82.00 \pm 0.000$ \\
\hline Low dose & $88.00 \pm 1.000$ & $88.67 \pm .577 \mathrm{abc}$ & $88.67 \pm .577 \mathrm{abc}$ & $87.33 \pm 1.155^{\mathrm{abc}}$ \\
\hline High dose & $88.00 \pm 1.000$ & $87.67 \pm .577 \mathrm{abc}$ & $86.33 \pm .577 \mathrm{abc}$ & $85.33 \pm .577 \mathrm{abc}$ \\
\hline
\end{tabular}

Table 7: Effect of Post - Inoculation Treatment with Goniopsis Pelli

Extract on Lymphocyte Count $\left(X 10^{3} / \mu l\right)$ in B. Pertussis Infected Mice

\begin{tabular}{|c|c|c|c|c|}
\hline & DAY 0 & DAY 6 & DAY 12 & DAY 18 \\
\hline Control & $2.00 \pm 0.000$ & $2.00 \pm 0.000$ & $2.00 \pm 0.000$ & $2.00 \pm 0.000$ \\
\hline Negative control & $4.67 \pm .577$ & $6.67 \pm .577$ & $9.00 \pm 1.000$ & $11.00 \pm 1.000$ \\
\hline Erythromycin & $4.67 \pm .577$ & $3.33 \pm .577$ & $2.67 \pm .577$ & $2.00 \pm 0.000$ \\
\hline Low dose & $4.67 \pm .577$ & $4.00 \pm 0.000^{\mathrm{ab}}$ & $4.00 \pm 0.000^{\mathrm{ab}}$ & $3.33 \pm .577 \mathrm{~b}$ \\
\hline High dose & $4.67 \pm .577$ & $4.00 \pm 0.000^{\mathrm{ab}}$ & $3.33 \pm .577 \mathrm{ab}$ & $3.33 \pm .577 \mathrm{~b}$ \\
\hline
\end{tabular}

Table 8: Effect of Post - Inoculation Treatment with Goniopsis Pelli

Extract on Monocyte Count $\left(X 10^{3} / \mu l\right)$ in B. Pertussis Infected Mice

\begin{tabular}{|c|c|c|c|c|}
\hline & DAY 0 & DAY 6 & DAY 12 & DAY 18 \\
\hline Control & $.40 \pm .0 .000$ & $.40 \pm 0.000$ & $.40 \pm 0.000$ & $.40 \pm 0.000$ \\
\hline Negative control & $0.00 \pm .0 .000$ & $0.00 \pm 0.000$ & $0.00 \pm 0.000$ & $0.00 \pm 0.000$ \\
\hline Erythromycin & $0.00 \pm .0 .000$ & $0.00 \pm 0.000$ & $.06 \pm .006$ & $.37 \pm .058$ \\
\hline Low dose & $0.00 \pm .0 .000$ & $0.00 \pm 0.000$ & $0.00 \pm 0.000^{\text {ac }}$ & $.07 \pm .012^{\text {ac }}$ \\
\hline High dose & $0.00 \pm .0 .000$ & $0.00 \pm 0.000$ & $.10 \pm 0.000^{\text {abc }}$ & $.14 \pm .012^{\text {abc }}$ \\
\hline
\end{tabular}

Table 9: Effect of Post - Inoculation Treatment with Goniopsis Pelli

Extract On Eosinophil Count $\left(X 10^{3} / \mu l\right)$ in B. Pertussis Infected Mice

\subsection{Histological Figure $s$}

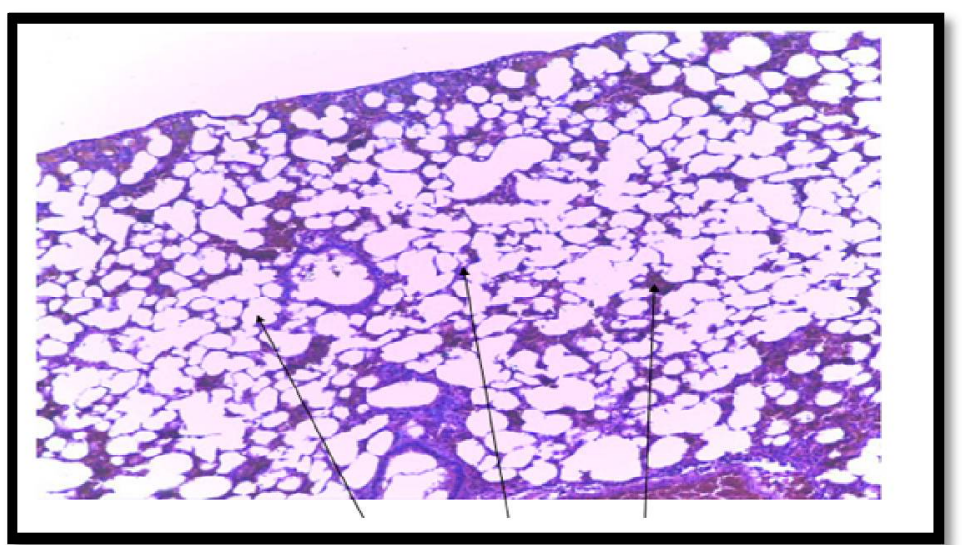

Figure 1: Photomicrograph of Lungs Tissue of Normal Mice Showing No Histologic Alteration 


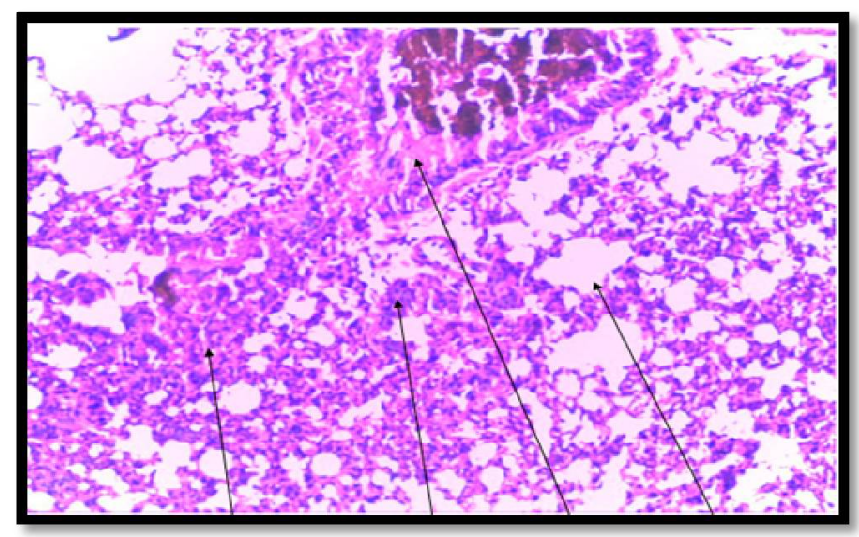

Figure 2: Photomicrograph of Lungs Of Mice Infected With B.Pertussis $S$ howing Interstitial Inflammation and Bullae Formation (Day 0)

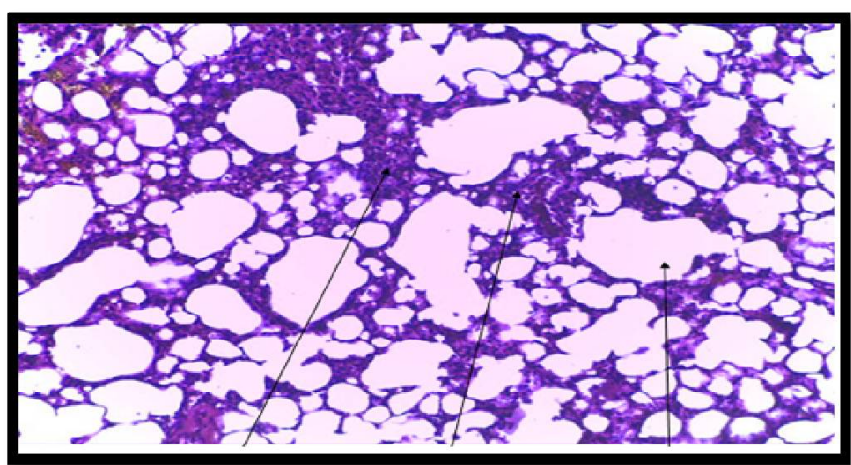

Figure 3: Photomicrograph of Lungs of Mice Infected with B.Pertussis without Treatment for 6days Showing Interstitial Inflammation and Bullae Formation

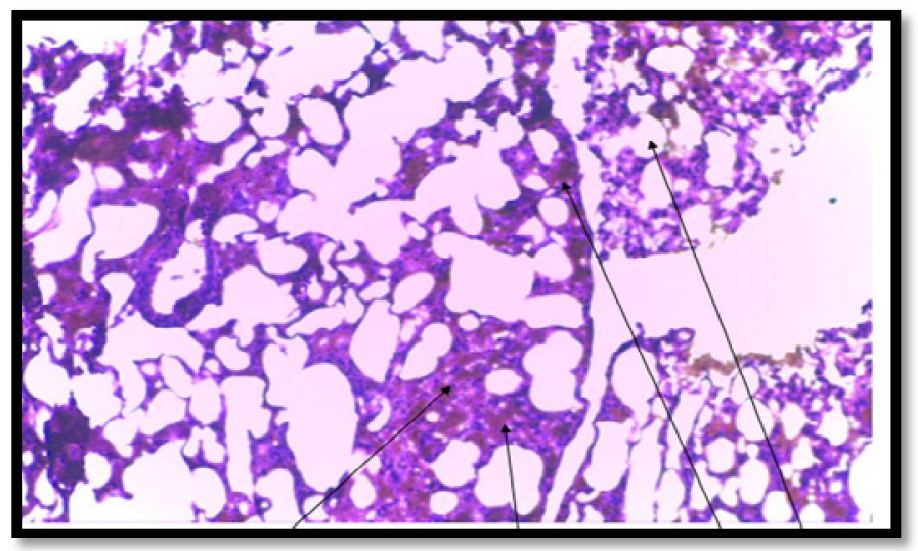

Figure 4: Photomicrograph of Lungs of Mice Infected with B.Pertussistreated with $4000 \mathrm{mg} / 70 \mathrm{~kg}$ of Erythromycin for 6days Showing Interstitial Inflammation And Bullae Formation

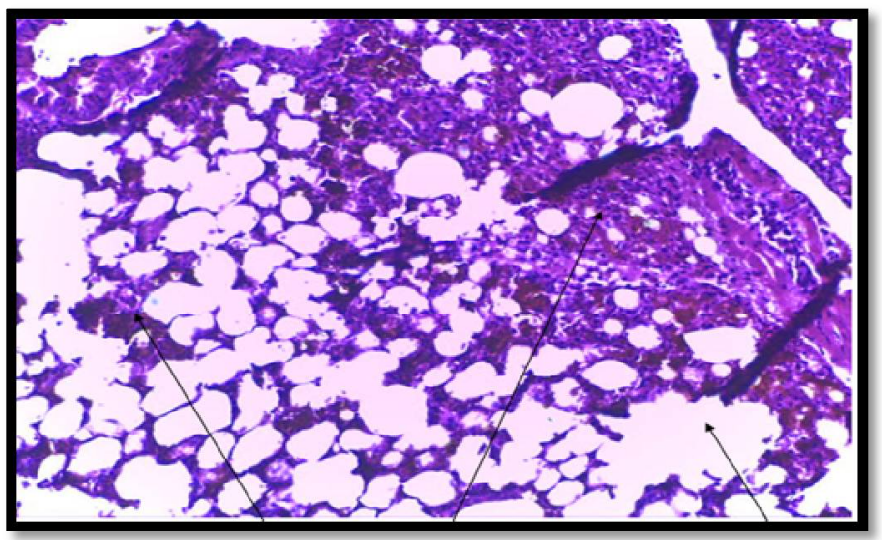

Figure 5: Photomicrograph of Lungs of Mice Infected with B. Pertussis and Treated with $300 \mathrm{mg} / \mathrm{Kg}$ of Goniopsis Pelli Extract For 6days Showing Interstitial Inflammation and Bullae Formation 


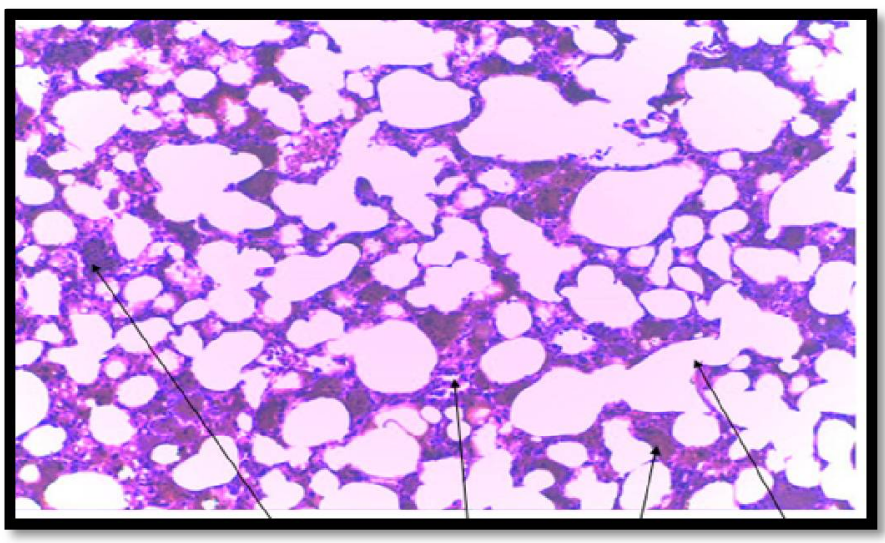

Figure 6: Photomicrograph of Lungs of Mice Infected with B.Pertussis and Treated with $600 \mathrm{mg} / \mathrm{Kg}$ of Goniopsis Pelli Extract for 6days Showing Interstitial Inflammation and Bullae Formation

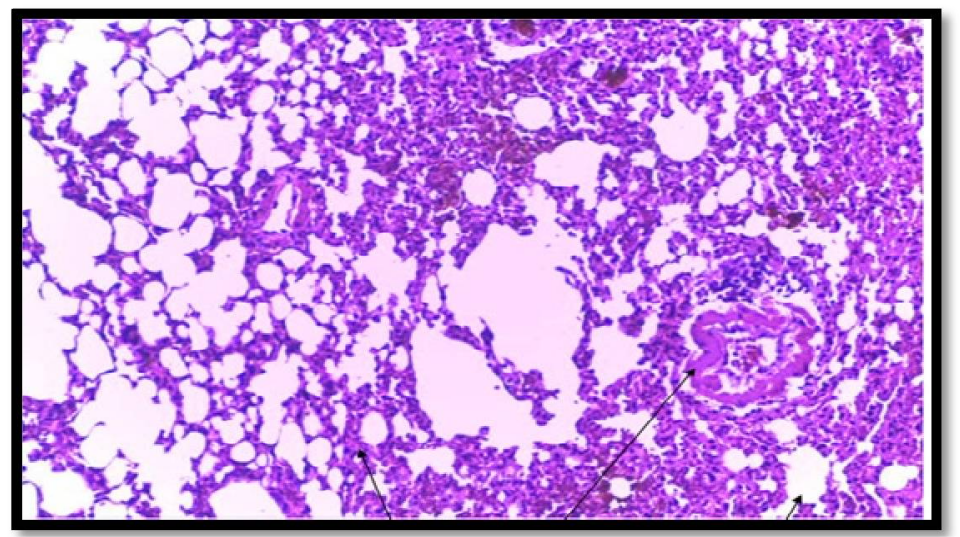

Figure 7: Photomicrograph of Lungs of Mice Infected with B.Pertussis without Treatment for 12days Showing Interstitial Inflammation and Bullae Formation

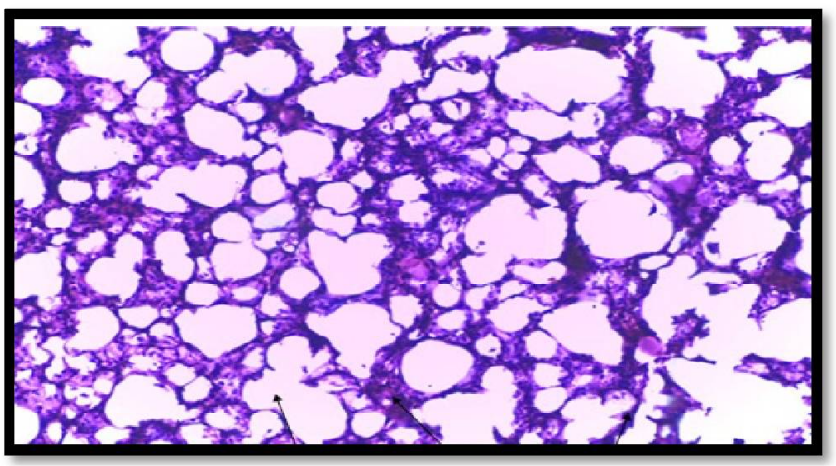

Figure 8: Photomicrograph of Lungs of Mice Infected with B.Pertussistreated with 4000mg/70kg of Erythromycin for 12days Showing No Obvious Histologic Change with Clear Alveolar Spaces and Pulmonary Vessels

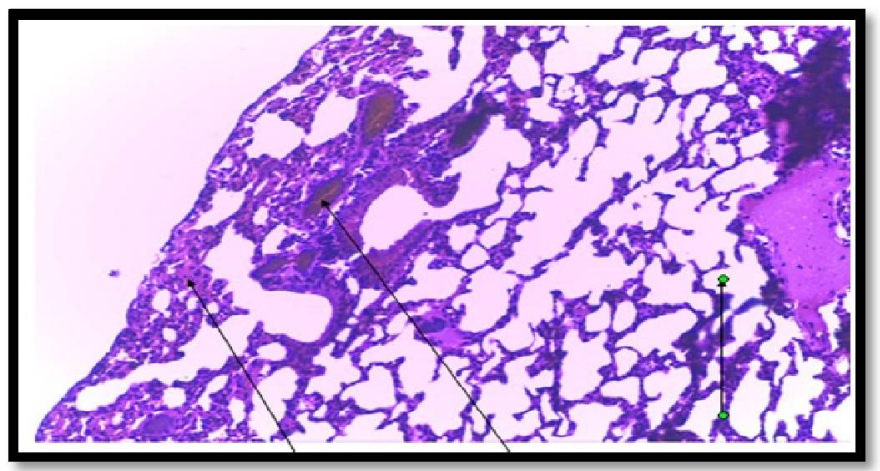

Figure 9: Photomicrograph of Lungs of Mice Infected with B.Pertussis and Treated with $300 \mathrm{mg} / \mathrm{Kg}$ of Goniopsis Pelli Extract for 12days Showing Mild Interstitial Inflammation and Bullae Formation 


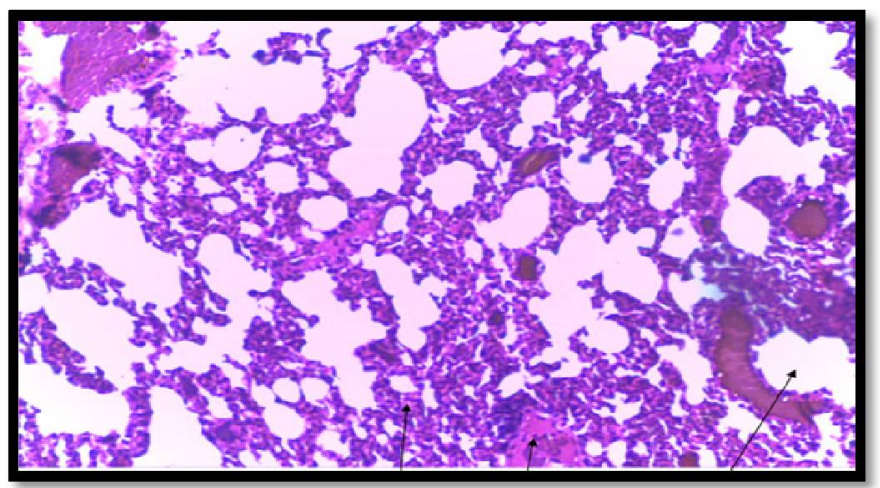

Figure 10: Photomicrograph of Lungs of Mice Infected with B.Pertussis and Treated with $600 \mathrm{mg} / \mathrm{Kg}$ of Goniopsis Pelli Extract for 12days Showing Mild Interstitial Inflammation and Bullae Formation

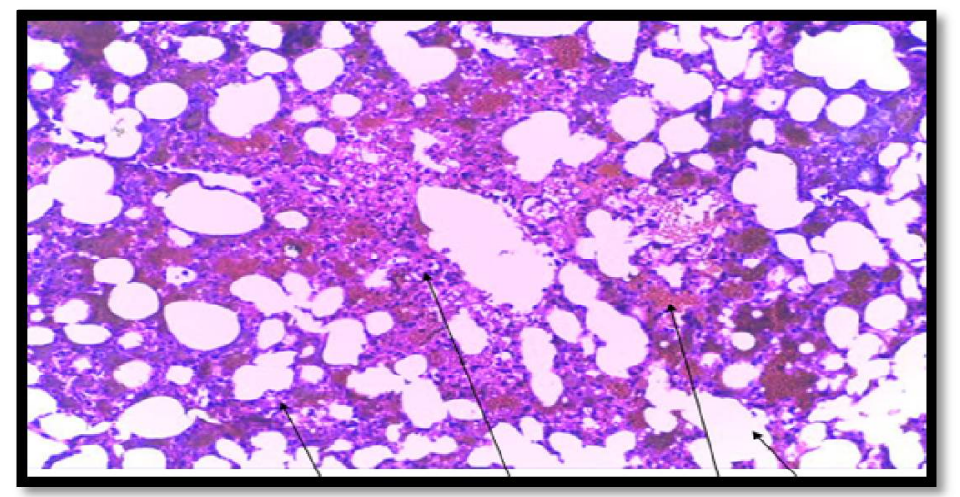

Figure 11: Photomicrograph of Lungs of Mice Infected with B.Pertussis without Treatment for 18days Showing Interstitial Inflammation and Bullae Formation

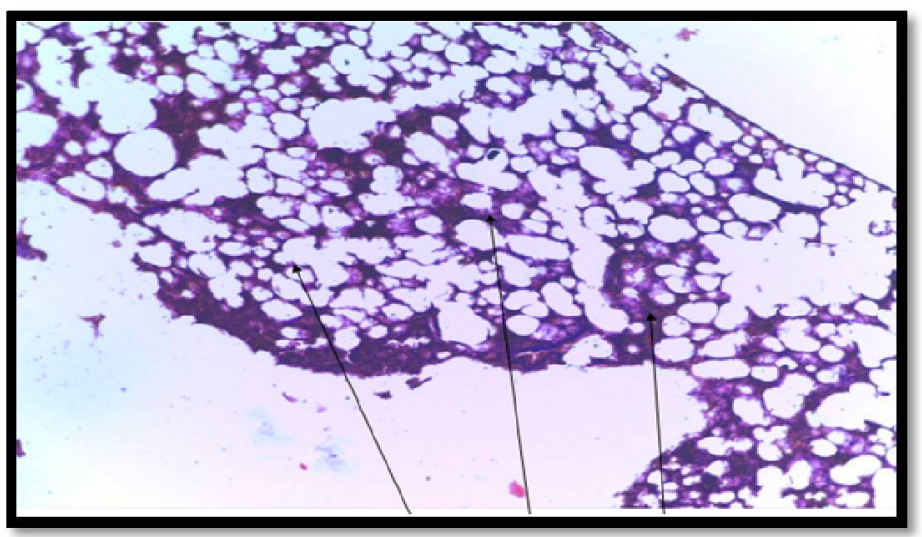

Figure 12: Photomicrograph of Lungs of Mice Infected with B.Pertussis and Treated with $4000 \mathrm{mg} / 70 \mathrm{~kg}$ of Erythromycin for 18days Showing No Obvious Histologic Change

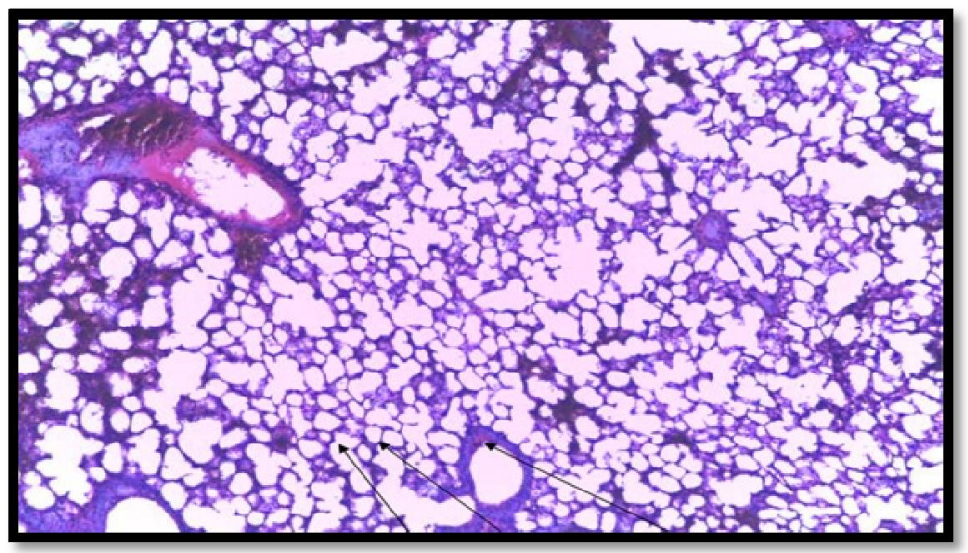

Figure 13: Photomicrograph of Lungs of Mice Infected with B.Pertussis and Treated with $300 \mathrm{mg} / \mathrm{Kg}$ of Goniopsis Pelli Extract for 18days Shows No Histologic Alteration 


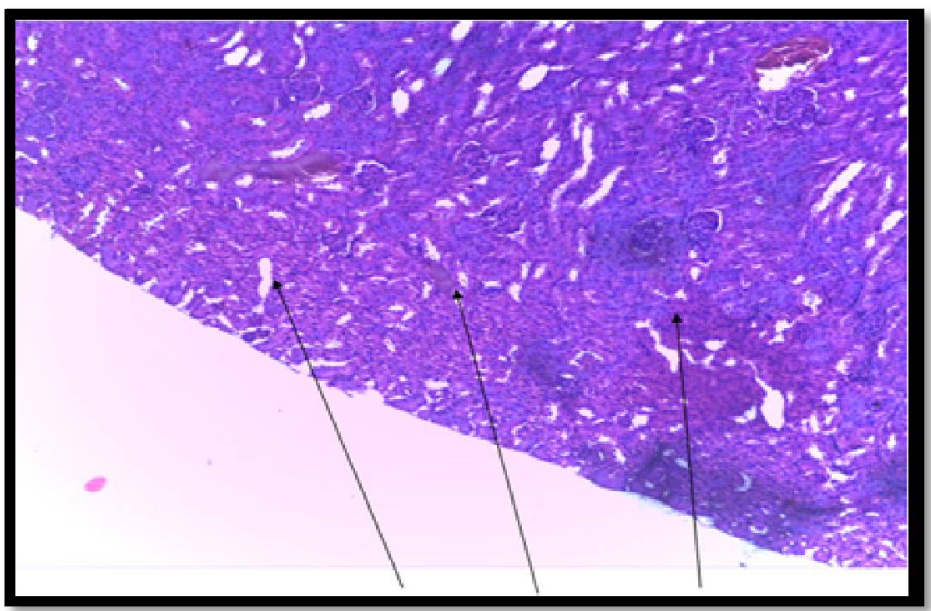

Figure 14: Photomicrograph of Lungs of Mice Infected with B.Pertussis and Treated with $600 \mathrm{mg} / \mathrm{Kg}$ of Goniopsis Pelli Extract For 18days Showing Normal Lungs with No Obvious Histologic Alteration

\section{Discussion}

Numerous research have shown that the regular hematological changes observed during B. pertussis infection include leukocytosis (an increase in the number of white blood cell (WBC)) lymphocytosis (an increase in the number of lymphocytes in the blood) and monocytosis (an increase in the number of monocytes in the blood (Back et al., 2014; Temple et al., 2009, Nguyen et al., 2015).significant decrease in mean levels of PCV (Pack Cell Volume), Red Blood Cell (RBC) an Hemoglobin while there is an increased neutrophil (Momoh et al, 2013). The result of this study agrees with the reports from the other researchers. The increase in neutrophil and while blood cell are associated with the invasion of the hemopoietic organ (bone marrow) by B. pertussis while monocytosis and lymphocytosis are attributed to the increased release of these cells from the myeloid/ lymphoid tissues in response to the infection (Das and Mukherjee, 2003, Anusuya and Sumathi, 2015). However, the decrease in RBC, PCV and hemoglobin could be as a result of the destruction of Red Blood Cell by the infection (Dangana et al., 2000) hemophagocytosis (a potentially fatal disease of normal but over active histiocytes and lymphocytes that are common in infants) and bone marrow suppression (Khosla et al., 1995). The result further reveals that the post inoculation treatment with Goniopsis pelli extract reversed the usual trend of significant increase $(\mathrm{P}<0.05)$ in $\mathrm{WBC}$, lymphocytes, monocytes, neutrophils and decrease in $\mathrm{PCV}, \mathrm{RBC}$, figure lets and hemoglobin usually associated with $B$. pertussis infection. Therefore, the post inoculation treatment with Goniopsis pelli extract reversed B. pertussis invasion of the hemopoietic organs, bone marrow suppression, destruction of RBC, hemophagocytosis and the invasion of the macrophages although the level of reversal is time and suggests that prophylactic and curative potentials of Goniopsis pelli extract against B. pertussis when combined with other therapeutic agents. The result of this study agrees with the report of Andreasen and Carbonetti, 2008, Karen et al., 2017 who said infection of $B$. pertussis causes lung tissue inflammation, necrosis and widened interstitial. However, treatment with Goniopsis pelli extract slowly reversed the trend with increase in time and dosage. The result confirms the antiBordetellapertussis property of the extract.

\section{Conclusion}

Inoculation of mice with an infective dose of B. pertussis produces hematological changes such as leukocytosis (an increase in the number of white blood cell (WBC)) lymphocytosis (an increase in the number of lymphocytes in the blood) and monocytosis (an increase in the number of monocytes in the blood) Significant decrease in mean levels of PCV (Pack Cell Volume), Red Blood Cell (RBC) and Hemoglobin with an increase in neutrophil but treatment with Goniopsis pelli extract reversed the changes in a dose and time dependent manner. Similar, infection with B.pertussis caused distortions in the lungs tissue such as widened interstitial inflammation and bullae formation but treatment with Goniopsis pelli extract reversed the changes in a dose and time dependent manner.

\section{References}

i. Andreasen, C. \& Carbonetti, N.H. (2008). Pertussis toxin inhibits early chemokine production to delay neutrophil recruitment in response to Bordetella pertussis respiratory tract infection in mice. Infections and Immunology, 76:5139-5148.

ii. Bae keun park (2010) "Application of chitin and its derivatives in biological medicine" international food research journal11(12): 5152-5164

iii. Beck, T.C., Gomes, A.C. \& Cyster, J.G. (2014) CXCR4 and a cell-extrinsic mechanism control immature B lymphocyte egress from bone marrow. Journal of Experimental Medicine.211:2567-81

iv. Dangana, A., Ajobiewe, J. and Nuhu, A. (2010). Hematological changes associated with Salmonella typhi and Salmonella paratyphi in humans. International journal of Biomedical Health Science, 6:219-222

v. Das, B.K. and Mukherjee, S.C. (2003). Toxicity of cypernethrin in Laberohita fingerlings: Biochemical enzymatic and haematological consequence. Journal of comparative Biochemistry, Physiology, Toxicology and Pharmacology, 134: $109-121$ 
vi. Dorji, D., Mooi, F., Yantorno, O., Deora, R., Graham, R.M. \& Mukkur, T.K. (2017). Bordetella Pertussis virulence factors in the continuing evolution of whooping cough vaccines for improved performance. Medical Microbiology and Immunology, 10:17-52

vii. Elahi, S., Brownlie, R. \& Korzeniowski, J. (2005). Infection of newborn piglets with Bordetella pertussis: a new model for pertussis. Infection and Immunology.73:3636-45.

viii. Garry Kerch, (2015) The potential of chitosan and its derivatives in prevention and treatment of age-related disease. International food research journal, 13:2158-2182

ix. Hinds, P.W., Yin, C. \& Salvato, M.S., (1996) Pertussis toxin induces lymphocytosis in rhesus macaques. Journal of Medical Primatol. 25:375-81.

x. Karen, M., Scanlon, Y., Snyder G. \&Nicolas, H. (2017) Fatal Pertussis in the Neonatal Mouse Model Is Associated with Pertussis Toxin-Mediated Pathology beyond the Airways. Infectious Immunology,85 (11):355-17.

xi. Khosla, S.N., Singh, R., Singh, G.P. \& Trehan, V.K. (1988). The spectrum of hepatic injury in enteric fever. American Journal of Gastrointestnal, 83:413-16.

xii. Mahae, N., Chalat, C. and Muhamud, P. (2011) Antioxidant and antimicrobial properties of chitosan sugar complex. International food research journal, 18 (4) 2011, page no 1543-1551.

xiii. Mattoo, S. \& Cherry, J.D. (2005). Molecular pathogenesis, epidemiology, and clinical manifestations of respiratory infections due to Bordetella pertussis and other Bordetella subspecies. Clinical Microbiology Review, 18:326-382.

xiv. Mead, R. \& Curnow, R. N. (1982). A simple statistical method in Agriculture and Experimental Biology. Charpman Hall, London, UK, 33-46

xv. Ming Kong, Ke xing \& Hyun kin park (2010). “Antimicrobial properties of chitosan and mode of action: A state of art review" International journal of food microbiology, 144 (1):50-63.

xvi. Momoh, A. O., Adebolu, T.T. \& Ogundare, A.O. (2013). Evaluation of beniseed extract and fermented liquors in treatment of diarrhea in albino rats infected with Salmonella typhi. European Journal of Biology and Medical Science Research, 1(2):16-23.

xvii. Nguyen, A.W., Wagner, E.K., Laber, J.R. (2015). A cocktail of humanized anti-pertussis toxin antibodies limits disease in murine and baboon models of whooping cough. Sci Transl Med.7:316-95

xviii. Randox Laboratories Limited (2015). 55 Diamond Road, Crumil. County Antrim, BT294QY, United Kingdom.

xix. Reitman, S. \& Frankel, S. (1957). A colorimetric method for the determination of serum glutamic oxalacetic and glutamic pyruvic transaminases. American journal of clinical pathology, 28:56-63

xx. Renata, A. S., Jose, R. F. and Fábio, H. V, (2012). Development of male reproductive system of the blue land crab Cardisoma guanhumi Latreille, 1828 (Decapoda: Gecarcinidae). Acta Zoologica,Volume 93, issue 4, pp 390-399

xxi. Sammy, D., Grave, N., Dean, P. and Pentcheff, N. (2009) A classification of living a fossil genera of decapod crustaceans. Raffles bulletin of zoology. 21:1-109

xxii. Schmidt, E. \& Schmidt, F. W. (1963) Enzyme. Biology and Clinical science, 3:1-6

xxiii. Shahidi, F. \& Synowiecki, J. (1991) Isolation and characterization of nutrients and value- added products from snow crab (Chionoecetes Opilio) and shrimp (Pandalus Borealis) processing discards. Journal of Agricultural Food Chemistry, 39 (8):1527-1532.

xxiv. Sheridan, S.L., Ware, R.S., Grimwood, K. \& Lambert, S.B. (2012) Number and order of whole cell pertussis vaccines in infancy and disease protection. JAMA308: 454-456

xxv. Sujeetha, M., Sharmila, S., Jayanthi, J. \& Ragunathan, G. (2015). Antioxidant property of some extracts derived from the mud crab, scylla serrate. International Journal of Phytopharmacology, 6 (2):111-113.

xxvi. Suneeta kumara (2014) Extraction and characterization of chitin and chitosan from (Labeo rohit) fish scales. Raffles bulletin of zoology,6:482-489. 